\title{
DESAIN APLIKASI ADMINISTRASI CURICULUM VITAE DOSEN DI LINGKUNGAN UNIVERSITAS MERDEKA MALANG
}

\author{
Rusdijanto \\ Fakultas Teknologi Informasi, Universitas Merdeka Malang \\ Email : Rusping27@gmail.com
}

\begin{abstract}
The purpose of this study was to create a design and prototype data processing lecturers Curriculum Vitae can be generated so that the output of information that has the characteristics, availability, easy to grasp, Relevant, Useful, Timely, Reliability, Accurate and Consistent The study used secondary data obtained from the documents in the civil service such as education history data. Then the document on the academic part of carrying out the education and teaching, while carrying out research and development and produce scientific papers, carry out community service from LPPM document. The amount of data is 336 people, both men and women with diverse groups of rank and in part to spread the eight positions in the work unit environment Malang Merdeka University. All the above data was collected with documentation technique is to copy the documents that are relevant to the design development curiculum vitae lecturer at Malang Merdeka University. From the results it can be concluded designing application design curiculum administration vitae can be used for academic services on campus and off campus faculty services so that the needs of faculty in academic, other needs related curiculum vitae can be served quickly. In the determination of policy, administrative application design can be used as a control tool to determine the development of each faculty in the respective majors on college Tridarma activities, also could provide another motivation for the professors to improve Tridarma activities and activities that are relevant outside the campus.
\end{abstract}

\section{Keywords : Design and curriculum vitae}

\section{PENDAHULUAN}

Media informasi saat ini berkembang pesat sekali, sejak komputer ditemukaan dan program aplikasi dibuat oleh banyak vendor, munculah berbagai macam bentuk program aplikasi. Pada generasi awal dikenal program aplikasi berbasis desktop (desktop based), lalu di awal tahun 90-an ketika internet mengalami perkembangan yang cukup pesat dengan banyaknya komputer yang terhubung ke internet, banyak pula aplikasi dan layanan yang berjalan di internet. Salah satunya adalah aplikasi berbasis (web based application). Organisasi sering dihadapkan pada situasi atau kondisi yang serba tidak pasti ataupun tidak menentu, banyak faktor yang mempengaruhi keberhasilan sebuah organisasi baik faktor internal maupun eksternal. Faktor internal adalah seluruh sumberdaya yang dimiliki baik SDM ataupun sumberdaya lainnya seperti modal, mesin dan lain-lain. Faktor eksternal mulai dari yang paling dekat seperti pelanggan, pemasok, sampai faktor yang jauh seperti kebijakan ekonomi, pemerintah dan kebijakan ekonomi global. Kebijakan manajemen dan sistem yang didukung dengan SDM yang handal serta tersedianya informasi yang relevan merupakan tolak ukur keberhasilan organisasi. Sedangkan informasi yang relevan bagi manajemen hanya dapat diperoleh melalui pengolahan data yang tepat. Berdasarkan praktek maupun penelitian para pakar serta praktisi organisasi, bahwa pekerjaan informasi dapat ditangani dan dilakukan secara sistematis dan praktis menggunakan Sistem Informasi Manajemen. Kemudian jumlah informasi yang tersedia di internet bertambah lebih dua kali lipat setiap tahun, dan banyak yang gratis. Internet dan berbagai jaringan telekomunikasi lainnya membawa banjir informasi kepada manajer. Oleh karena itu, kemampuan akses, navigasi dan manajemen data informasi serta pengetahuan yang dibutuhkan untuk pengambilan keputusan manajerial sangatlah penting. Salah satunya solusi yang efektif disediakan oleh teknologi informasi. 
Saat ini perkembangan ilmu pengetahuan dan teknologi terutama bidang komputer dan bidang komunikasi sangat berpengaruh terhadap kemajuan pekerjaan di organisasi. Dengan bantuan komputer, pekerjaan dapat dikerjakan lebih mudah, cepat, bervariasi, dan lebih banyak. Penggabungan komputer dengan alat komunikasi telah menghasilkan peralatan kantor yang canggih dan dapat mengkomunikasikan data dan informasi pekerjaan atau hasil kerja dengan cepat di dalam kantor, antar kantor, dan antar Negara di seluruh dunia. (Amsyah, 1997:107).

Dengan kemajuan peralatan pengolahan data sehingga menjadi informasi yang tepat, cepat, dan akurat yang dibutuhkan oleh manajemen, maka manusia makin sadar akan pentingnya informasi. Oleh karena itu makin disadari bahwa informasi yang tersedia dengan cepat, tepat dan teliti, serta dapat dikomunikasikan sesuai dengan keperluan, maka pekerjaan manajemen dalam organisasi dan pelayanan organisasi kepada masyarakat akan dapat dikerjakan dengan sebaikbaiknya. Sistem informasi manajemen berbasis komputer tidak hanya bermanfaat dalam pendokumentasian organisasi namun juga dapat menjadi pendukung pedoman bagi pengambil kebijakan / pengambil keputusan di Perguruan tinggi / Decision Support System dan Executive Information System Dengan adanya data yang akurat pada organisasi maka data ini juga dapat digunakan untuk informasi bagi karyawan yang lain. Oleh karena itu sistem informasi manajemen berbasis komputer ini sangat penting dan sangat dibutuhkan oleh manajemen organisasi, dimana aktifitas organisasi dapat termonitor dalam sebuah data base yang baik. Manfaat lain yang dapat diperoleh dari sistem informasi yang berbasis komputer ini ialah system ini sangat praktis karena mampu menyimpan data yang sangat banyak penuh dalam sebuah kotak kecil / hard disk yang berukuran hanya $15 \times 10 \times 5 \mathrm{~cm}$. Sistem informasi berbasis komputer juga dirancang untuk mengikuti era globalisasi, oleh karena itu semakin tingginya kemampuan teknologi computer dan murahnya biaya pemanfaatan telah menghasilkan jaringan komunikasi yang kuat yang dapat digunakan organisasi untuk melakukan akses informasi dengan cepat dari berbagai penjuru dunia serta untuk mengendalikan aktivitas yang tidak terbatas pada ruang dan waktu. Jaringan-jaringan ini telah mentransformasikan ketajaman dan bentuk aktivitas organisasi, menciptakan fondasi untuk memasuki era digital. Untuk mewujudkan perubahan manajemen data personalia pada suatu organisasi di Universitas Merdeka Malang yang selama ini menggunakan secara manual dan dalam distribusinya ke masing-masing satker membutuhkan waktu lama maka diperlukan inovasi terutama bentuk tampilan, pengisian data yang lebih cepat, memudahkan penyampaian informasi data, dan dapat diakses dengan cepat terutama yang nengakses berda pada posisi diluar kota maupun di luar Negeri yaitu dengan memfaatkan teknologi Web yang berkembang pada saat ini dapat mudah di perolehnya.

Melihat kemampuan Teknologi Web dalam aplikasi menjalankan dokumen-dokumen Web melalui browser, maka penulis tertarik untuk medesain aplikasi Pengarsipan Curiculum Vitae Dosen Karyawan di lingkungan Universitas Merdeka Malang.

\section{Manajemen Sistem informasi}

Sistem Informasi merupakan suatu sistem yang tujuannya menghasilkan suatu informasi. Sistem adalah rangkaian dari dua atau lebih komponen - komponen yang saling berhubungan, yang berinteraksi untuk mencapai suatu tujuan tertentu (Jogiyanto, 2005:34).

\section{a. Analisis Sistem}

Analisis sistem dapat didefinisikan sebagai penguraian dari suatu sistem informasi yang utuh ke dalam bagian - bagian komponennya dengan maksud untuk mengidentifikasikan dan mengevaluasi permasalahan - permasalahan, kesempatan -kesempatan, hambatan - hambatan yang terjadi dan kebutuhan - kebutuhan yang diharapkan sehingga dapat diusulkan perbaikan perbaikannya (Jogiyanto, 1999:129).

Tujuan utamanya adalah untuk memahami sistem dan masalah yang ada, untuk menguraikan kebutuhan informasi dan untuk menetapkan prioritas pekerjaan sistem selanjutnya. 


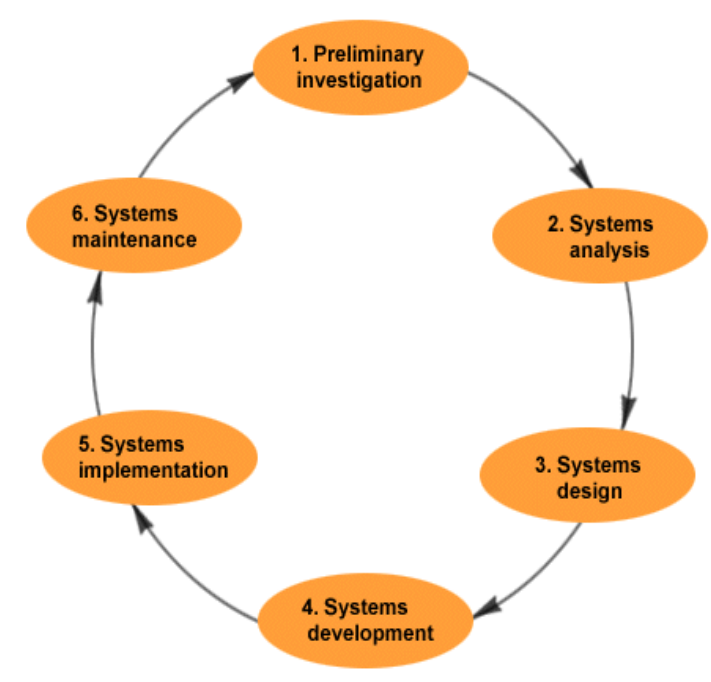

Gambar 1 Bagan System Development Live Cycle(SDLC)

Terdapat empat tahap atau langkah umum dalam analisis sistem :

1. Survei sistem berjalan.

2. Mengidentifikasi kebutuhan informasi pemakai.

3. Menentukan keluaran yang diperlukan oleh pemakai

4. Melakukan desain system

\section{Desain Sistem}

Setelah tahap analisis sistem selesai dilakukan, maka analisis sistem telah mendapatkan gambaran dengan jelas apa yang harus dikerjakan. Tahap desain sistem mempunyai dua tujuan utama, yaitu :

1. Untuk memenuhi kebutuhan kepada pemakai sistem.

2. Untuk memberikan gambaran yang jelas dan rancang bangun yang lengkap kepada pemrogram komputer dan ahli - ahli teknik lainnya yang terlibat.

3. Untuk mencapai tujuan ini, analis sistem harus dapat mencapai sasaran-sasaran sebagai berikut :

a. Desain sistem harus berguna, mudah dipahami dan nantinya mudah digunakan.

b. Desain sistem harus dapat mendukung tujuan utama perusahaan.

c. Desain sistem harus efisien dan efektif untuk dapat mendukung pengolahan transaksi, pelaporan manajemen dan mendukung keputusan yang akan dilakukan oleh manajemen, termasuk tugas-tugas lainnya yang tidak dilakukan oleh komputer. d. Desain sistem harus dapat mempersiapkan rancang bangun yang terinci untuk masingmasing komponen dari sistem informasi yang meliputi data, informasi serta pengendalian intern.

Desain sistem merupakan formulasi spesifikasi rinci dari sistem yang diusulkan.

Membangun sistem

Pada tahap ini, programmer, desainer, dan teknisi membangun sistem informasi sesuai dengan desain yang dihasilkan.

Implementasi sistem

Sistem telah dianalisis dan didesain secara rinci dan teknologi telah diseleksi dan

dipilih. Tiba saatnya sekarang sistem untuk diimplementasikan. Tahap implementasi sistem dapat terdiri dari langkah-langkah sebagai berikut ini :

1. Menerapkan rencana implementasi.

2. Melakukan kegiatan implementasi.

3. Tindak lanjut implementasi

Konsep siklus hidup mempunyai implikasi bahwa setiap proyek pengembangan sistem harus dibagi dalam tahap - tahap berbeda dengan titik pengendalian manajemen yang formal diletakkan diantara tahap-tahap. Prinsip pengendalian dasar adalah setiap tahap harus menghasilkan dokumentasi secara formal ditelaah dan disetujui sebelum memulai tahap berikutnya dari siklus hidup proyek.

6. Pemeliharaan sistem

\section{Komponen Sistem Informasi Manejemen}

Dalam rangka memudahkan dalam pembahasan selanjutnya, maka istilah yang digunakan dalam pembahasan ini adalah Komponen Sistem Informasi Manajemen, kemudian membahasnya secara bagian demi bagian mulai dari system, kemudian data dan informasi dan diakhiri dengan pembahasan tentang manajemennya.

\section{Sistem}

1) Pemahaman tentang system secara sederhana yaitu suatu system dapat diartikan suatu kumpulan atau himpunan unsur, komponen atau variable-variabel yang terorganisir, saling berinteraksi, saling tergantung satu sama lain dan terpadu. 
2) Definisi Sistem Informasi menurut Mulyanto (2009:29) adalah suatu komponen yang terdiri dari manusia, teknologi informasi, dan prosedur kerja yang memproses, menyimpan, menganalisis, dan menyebarkan informasi untuk mencapai suatu tujuan.

3) Suatu system pada dasarnya adalah sekelompok unsur yang erat hubungannya satu dengan yang lain yang berfungsi bersama-sama untuk mencapai tujuan tertentu. Secara sederhana, suatu system dapat diartikan sebagai suatu kumpulan atau himpunan dari unsure kumpulan atau himpunan dari unsure, komponen atau variable yang terorganisir, saling berinteraksi, saling tergantung satu sama lain dan terpadu.

Adapun ciri-ciri dari sebuah sistem adalah sebagai berikut:

1. Mempunyai tujuan tertentu atau memiliki kemampuan untuk memenuhi kebutuhan tertentu.

2. Bersifat alamiah dan buatan.

3. Terdiri dari subsistem-subsistem.

4. Memiliki batas-batas luar yang memisahkannya dengan lingkungan (suprasistem).

5. Bersifat terbuka atau tertutup. Terbuka berarti menerima input dari dan mengeluarkan output kesuprasistem. Sedangkan tertutup berarti tidak menerima input dari dan juga ke supra system.

Dengan demikian system adalah kumpulan dari bagian-bagian atau hal-hal yang berkaitan satu sama lain sehingga membentuk satu kesatuan.

\section{Informasi}

Secara umum dapat didefinisikan sebagai hasil dari pengolahan data dalam suatu bentuk yang lebih berguna dan lebih berarti bagi penerimanya yang menggambarkan suatu kejadian-kejadian yang nyata yang digunakan untuk pengambilan keputusan. Informasi merupakan data yang telah diklasifikasikan atau diolah atau diinterpretasi untuk digunakan dalam proses pengambilan keputusan.

Informasi bagian kajian ilmiah mengandung perbedaan yang mendasar. Data menunjuk kepada fakta-fakta baik berupa angka, teks, dokumen, gambar, bagan, suara yang mewakili aspirasi verbal atau kode tertentu dan semacamnya. Apabila telah tersaring dan diolah melalui suatu system pengolahan sehingga memiliki arti dan nilai bagi seseorang, maka data itu berubah fungsi menjadi informasi. Dengan demikian yang dipakai orang dalam membuat keputusan adalah informasi.

Informasi terdiri dari data yang diambil dan diolah atau digunakan untuk memberi dukungan keterangan bagi pengambilan keputusan, argumentasi, dan atau bagi dasar untuk peramalan atau pengambilan keputusan. Dengan demikian informasi adalah data yang telah disusun sedemikian rupa sehingga bermakna dan bermanfaat karena dapat dikomunikasikan kepada seseorang yang akan menggunakannya untuk membuat keputusan.

Untuk dapat memperoleh informasi pemakai data harus mengetahui jenis keterangan yang diperlukan dan bagaimana system penyimpanan datanya. Hal ini yang kemudian dimanfaatkan oleh penjual jasa informasi untuk menyediakan informasi yang diperlukan secara cepat dan tepat oleh konsumennya. Untuk selanjutnya informasi dikumpulkan kembali dan disimpan, kelak akan dimanfaatkan kembali dan dapat berfungsi sebagai data lagi.

\section{METODE PENELITIAN}

Dalam rancangan penelitian yang dilakukan pengumpulan data yang dipergunakan adalah data sekunder, yaitu data Dosen karyawan di lingkungan Universitas Merdeka Malang beralamat di Jalan Raya Dieng No. 62-64 Kota Malang. Adapun jumlah Dosen yang ada sampai sekarang adalah berjumlah 336 orang baik Lakilaki maupun perempuan dengan beraneka ragam golongan kepangkatan serta sebagaian menduduki jabatan menyebar pada delapan Satuan Kerja di lingkunghan Universitas Merdeka Malang. Dari data tersebut akan di olah menjadi sebuah bahan rancangan pengadministrasi Curiculum vitae Dosen berbasis Intranet atau internet.

Dalam perkembangan ilmu manajemen Informasi maka biodata, hasil karya penelitian, pengabdian mayarakat dan lain-lain perlu dibuat suatu rancangan aplikasi admistrasi curiculum vitae Dosen Universitas Merdeka Malang mengingat selama ini secara manual dipertimbangkan agar berubah menjadi lebih maju atau berkembang model adminitrasinya, seragam sesuai format BPMU dan mudah diakses oleh semua satuan kerja yang ada melalui jaringan intranet.

Sumber data yang digunakan dalam penelitian ini adalah data sekunder. Data sekunder dalam penelitian ini diperoleh dari 
dokumen pada bagian kepegawaian seperti data dosen seperti riwayat pendidikan. Dari bagian akademik yaitu melaksanakan pendidikan dan pengajaran, sedangkan melaksanakan penelitian dan pengembangan serta menghasilkan karya ilmiah, melaksanakan pengabdian kepada masyartakat didapat dari LPPM

\section{Pembuatan Rancangan Aplikasi}

Administrasi curiculum vitae Dosen $\mathrm{di}$ lakukan di Universitas Merdeka Malang J1 Raya Dieng No. 62-64 Malang, dengan Pertimbangkan:

1. Pertimbangan efisiensi sumber daya penulis

2. Memungkinkan rancangan ini untuk dapat diaplikasikan secara langsung sehingga bermanfaat secara praktis dinikmati oleh organisasi

Data dalam penelitian ini dikumpulkan dengan teknik dokumentasi yaitu dengan mengkopy dukumen-dukumen yang relevan dngan pengembangan desain curriculum vitae dosen di Universitas Merdeka Malang

Pada perancangan atau desain pengadministrasi curiculum vitae Dosen berbasis Intranet menggunakan beberapa intrumen sebagai berikut :

Perangkat Keras

a. PC yang terhubung dengan jaringan menggunakan Intel Duel Core 2,2 GHz

b. Memori DDR2 $1 \mathrm{~GB}$

c. Harddisk $40 \mathrm{~GB}$, untuk software Data 2 GB

d. VGA minimal $64 \mathrm{MB}$

Selain itu komponen tersebut diatas juga diperlukan jaringan yang terhubung dalam Local Area Network ( LAN)

\section{HASIL DAN PEMBAHASAN}

Pembahasan desai aplikasi adminitrsi curiculum vitae ini dilakukan dengan beberapa tahapan sebagai berikut :

Dari permasalahan yang iuraikan diatas maka dirancang koneksi sistem Informasi curiculum vitae dosen seperti gambar berikut :

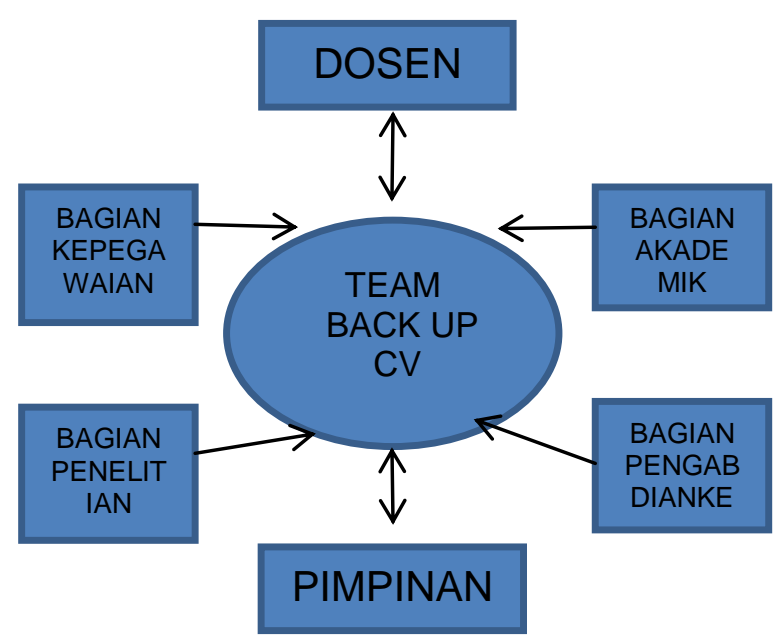

Gambar 2. Diagram koneksi Sistem Informasi yang dirancang

Dari gambar diatas dapat dijelaskan bahwa sistem koneksi sistem informasi curiculum vitae yaitu :

1. Dosen dapat meberikan data terkait data tambahan yang belum atau baru terkait kegiatan tridarmanya yang telah dilakuakan, dan setiap dosen dapat mengakses Curiculum Vitae baik di masing-masing satker maupun di tempat yang jauh sekalugus bisa melakukan cross cek kebenaran datanya.

2. Dari bagian kepegawaian meneruskan data dosen mengenai identitas diri yang memuat Nama, NIP/NIK, Gol/Pangkat, jabatan akademik dll, riwayat pendidikan yang telah di entry sebelunya ke Team Back Up Curiculum Vitae dan menerima revisi dari Team Back Up Curiculum Vitae yang telah dicek kebenaranya.

3. Dari bagian akademik meneruskan data dosen mengenai pengalaman mengajar, pelatihan profesional, produk bahan ajar, ke Team Back Up Curiculum Vitae

4. Bagian Penelitian / LPPM meneruskan data mengenai pengalaman penelitian, karya ilmiah, dan peserta konfrensi / seminar / lokakarya / simposium ke Team Back Up Curiculum Vitae

5. Bagian pengabdian kepada masyarakat meneruskan data dosen mengenai jabatan dalam pengelolaan institusi, peran dalam kegiatan mahasiswaan, piagam/penghargaan yang didapat, mengikuti organisasi profesi/ilmiah dan organiosasi ke 
masyarakatan ke Team Back Up Curiculum Vitae

6. Pimpinan sebagai pemegang kebijakan dapat mengakses data curiculum vitae dosen masing-masing satker, dan mengevaluasi kegiatan dosen tridarma perguruan tingg yang telah dilakukan.

Struktur Basis Data.

ERD diperlukan dalam pembuatan desain sistem ditunjukian oleh beberapa gambar yang terkait dengan curiculum vitae sebagai berikut :

1. Relasi dosen dengan riwayat pendidikan, jenjang, jawabatan, intitusi, perguruan tinggi, jalur dan satker dapat dilihat pada gambar dibawah ini

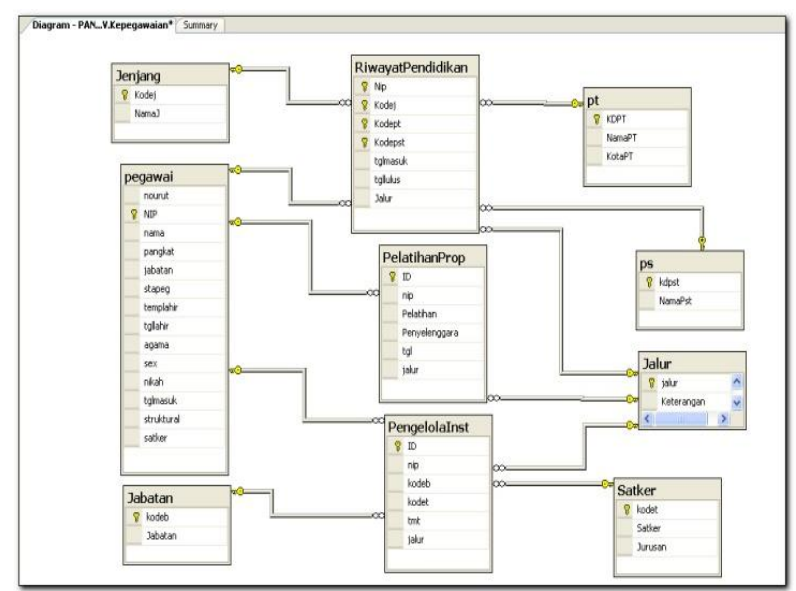

Gambar 3. Entity Relationship Diagram (ERD)

Sistem Informasi dosen dengan riwayat pendidikan

2. Relasi dosen dengan akademik, menunjukan dosen mengajar matakuliah pada jenjang $\mathrm{S} 1$, S2, S3 pada satkernya yang ada pada di perguruan tinggi. Hubunganya digambarkan sesuai dibawah ini

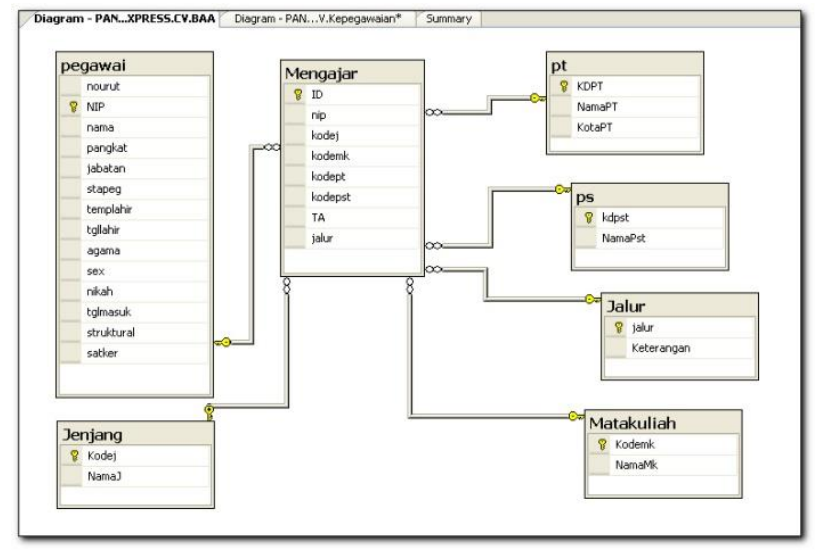

Gambar 4 Entity Relationship Diagram (ERD) Sistem Informasi dosen dengan riwayat mengajar

3. Relasi dosen dengan kegitan mahasiswa artinya dosen melakukan kegiatan melibatkan mahasiswa berupa bimbinganbimbinganpelatihan, penelitian dll.

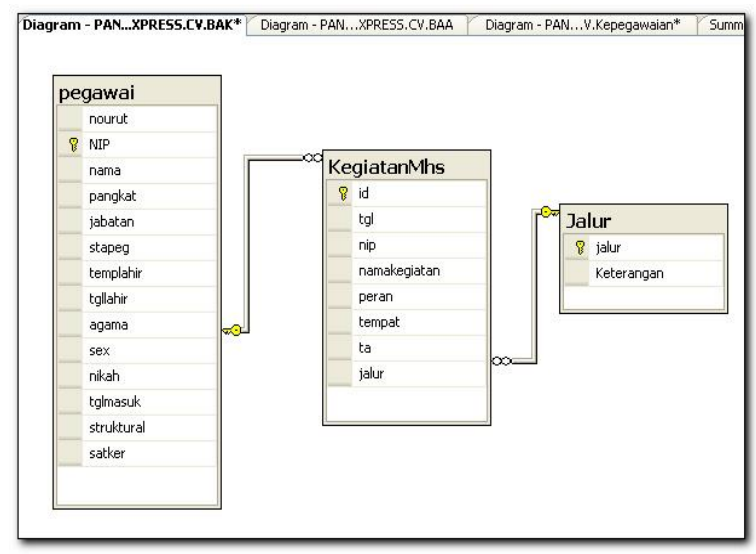

Gambar 5 Entity Relationship Diagram (ERD)

Sistem Informasi dosen dengan Mahasiswa.

4. Relasi dosen dengan penelitian, produk ajar, karya ilmiah artinya dosen melakukan kegiatan penelitian dengan sumber dana yang diperoleh, membuat buku atau modul matakuliah yang di emban sesuai jenjang, membuat karya ilmiah sesuai jalur dan publikasinya. 


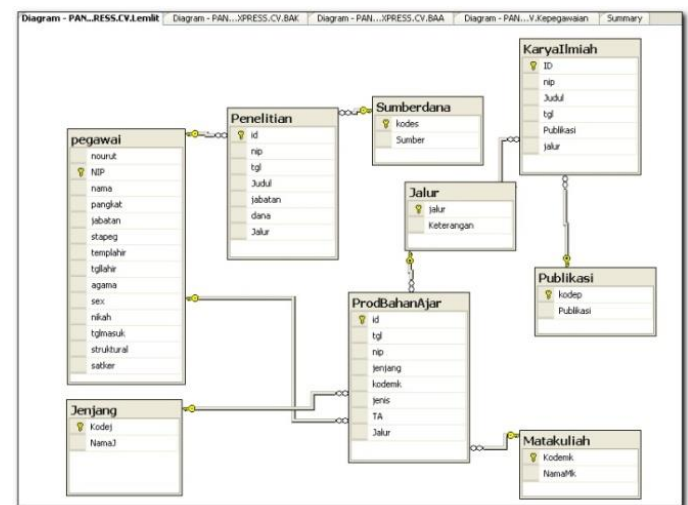

Gambar 6 Entity Relationship Diagram (ERD)

Sistem Informasi dosen dengan pengalaman penelitian, karya ilmiah, dan produk mengajar

\section{Struktur Desain Web}

Dari struktur data base yang tersusun selanjutnya dibuat desain web yang mana dimulai dari tampilan data semua data dosen kemudian tampilan yang lain dengan melakukan tiga penelusuran yaitu :

1. Penelusuran dengan NIP, akan muncul tampilan detail identitas dosen, riwayat pendidikan, pelatihan profesional, pengalaman mengajar, produk bahan 2. ajar, pengalamam penelitian

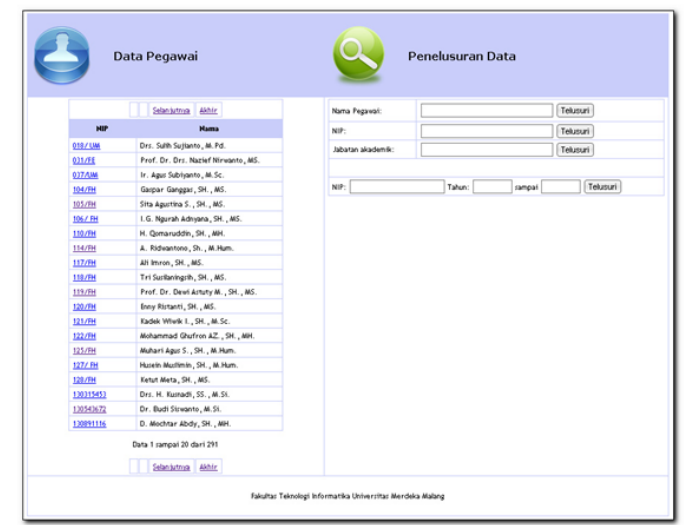

Gambar 7. Data pegawai dan penelusuran

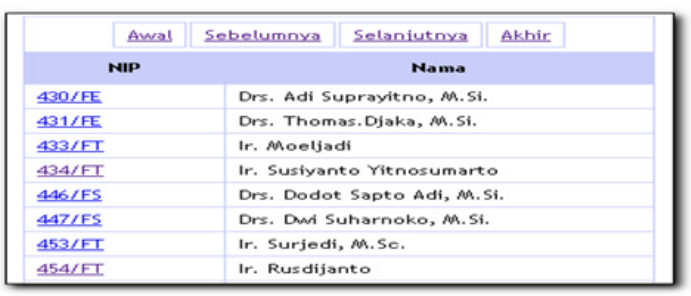

Gambar 8. Daftar NIP dan Nama Dosen

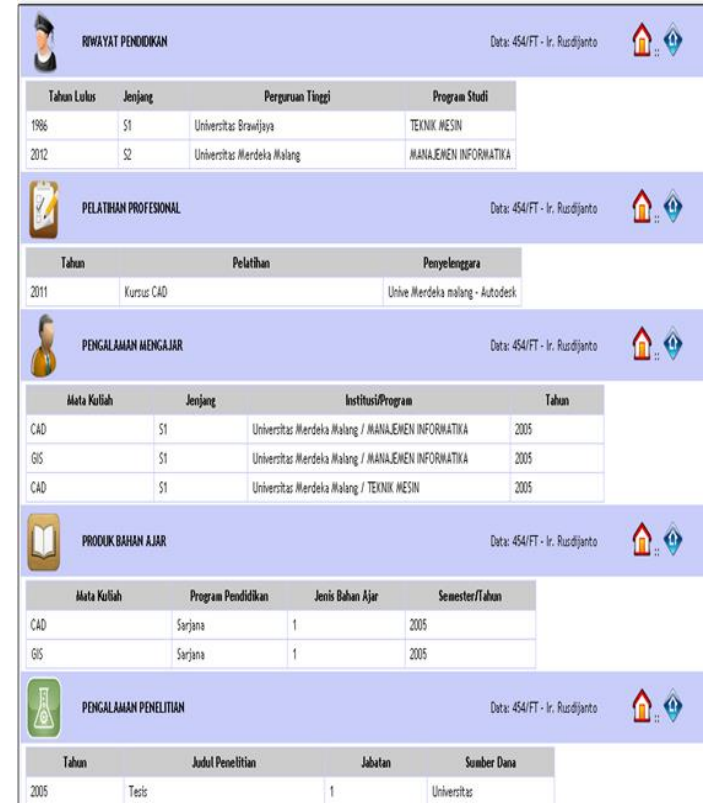

Gambar 9. Detail indentitas Pegawai dari hasil memasukan NIP

3. Penelusuran Nama, akan muncul tampilan hasil penelusuran data pegawai dimana semua pegawai yang namanya mengandung kata kunci yang diinputkan akan ditampilkan.

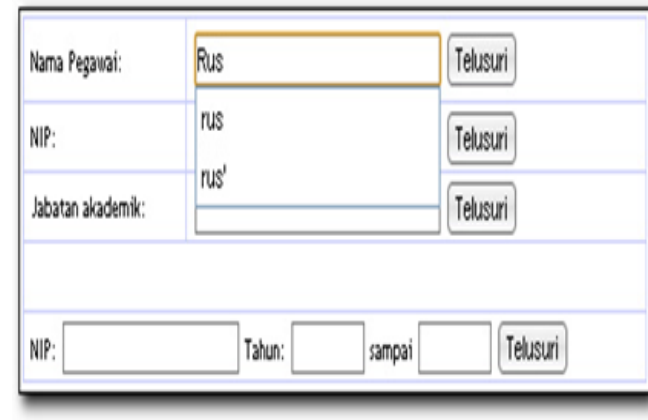

Gambar 10. Tampilan Kolom untuk penelusuran NAMA

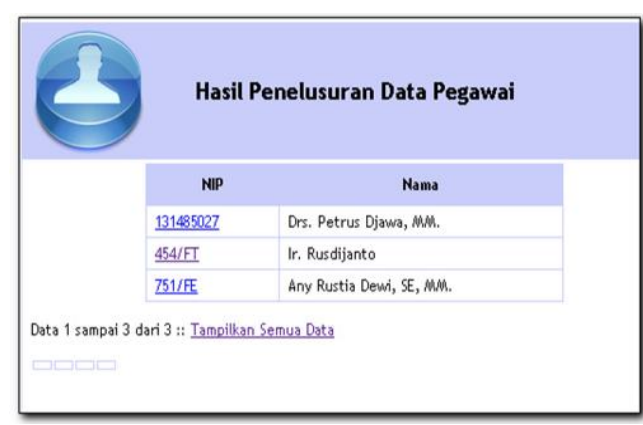

Gambar 11. Hasil penelusuran Data pegawai 
4. Penelusuan NIP dan tahun profil, disini memasukan kata kunci dari nama dan periode tahun pada kolom pencarian akan muncul misal pengalaman ngajar dan karya ilmiah
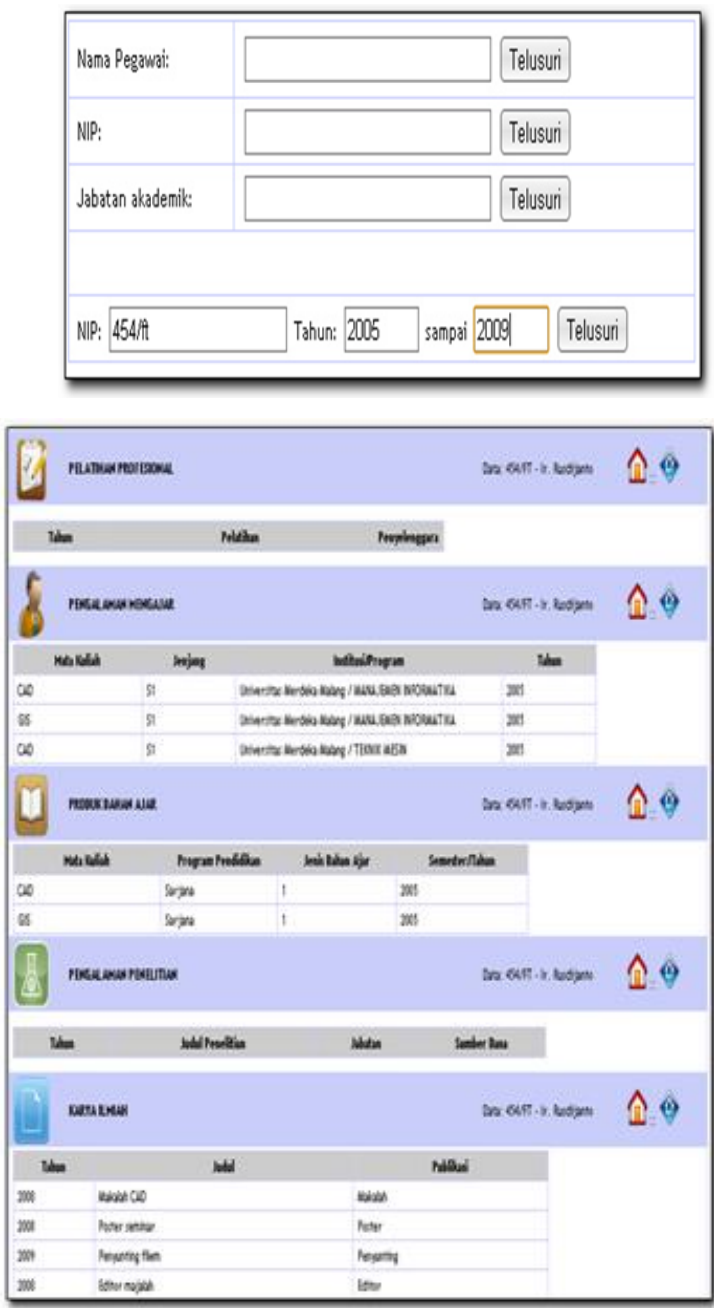

Gambar 12. Kolom penelusuran NIP dan Periode tahun

Dari sistem koneksi, struktur basis data, struktur desain web diatas maka memungkinkan diaplikasikan di tempat pengambilan data dosen yaitu Universitas Merdeka Malang untuk meningkatkan pelayanan administrasi, keperluan borang akriditasi masing-masing satker yang ada. Kemudian dihubungkan dengan jaring yang ada selama ini dengan pertimbangan sebagai berikut

1. Desain aplikasi adminstrasi curiculum vitae dapat digunakan untuk pelayanan akademik dikampus, dan pelayanan dosen diluar kampus sehingga kebutuhan dosen dibidang akademik, kebutuhan lainya terkait curiculum vitae dapat dilayani dengan cepat.

2. Dalam penentuan kebijakan, desain aplikasi adminitrasi dapat dugunakan sebagai alat kontrol untuk mengetahui perkembangan setiap dosen dimasing-masing satker yang ada mengenai kegiatan tridarmana perguruan tinggi, juga bisa memberi motivasi bagi dosen yang lain untuk meningkatkan kegiatan tridarmanya serta kegiatan yang yang relevan diluar kampus.

\section{Transformasi data}

Merupakan proses perubahan format data dari satu format ke format yang lain. Proses transformasi data dilakukan oleh Pusat komputer yang akan mentransform file format excel agar dapat ditransfer ke dalam format SQL Server. Sebagai contoh pada gambar 13, tabel yang secara terus menerus di update oleh bagian kepegawaian adalah tabel Riwayat pendidikan, pelatihan prop, dan pengelolaan inst.

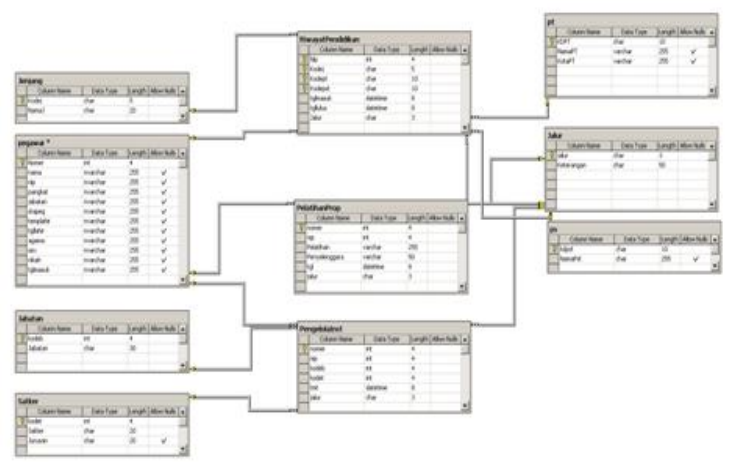

Gambar 13. Tabel master dan transaksi

Tahap-tahap transformasi data dari format excel ke format SQL server adalah sebagai berikut :

a. Pengisian data di sheet excel pengisian data di sheet excel dilakukan sesuai dengan prosedur pengisian data excel dengan ketentuan header yang sama dengan table tujuan.

Sebagai contoh, untuk persiapan data / table riwayat pendidikan

Data pada format excel diisi sesuai dengan kebutuhan, kemudian disimpan dalam format Exce197-2003, sebagaimana terlihat pada gambar 14. 


\begin{tabular}{|c|c|c|c|c|c|}
\hline \multicolumn{6}{|c|}{ RiwayatPendidikan } \\
\hline & Column Name & Data Type & Length & Allow Nulls & $\triangle$ \\
\hline 9 & Nip & int & 4 & & \\
\hline 9 & Kodej & char & 5 & & \\
\hline 8 & Kodept & char & 10 & & \\
\hline 9 & Kodepst & char & 10 & & \\
\hline & tglmasuk & datetime & 8 & & \\
\hline & tgllulus & datetime & 8 & & \\
\hline & Jalur & char & 3 & & \\
\hline 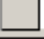 & & & & & $\nabla$ \\
\hline
\end{tabular}

\begin{tabular}{|c|c|c|c|c|c|c|c|}
\hline \multicolumn{3}{|c|}{ L14 } & \multicolumn{2}{|c|}{ - $\left(3 \quad f_{x}\right.$} & \multirow[b]{2}{*}{$\mathrm{E}$} & \multirow[b]{2}{*}{$\mathrm{F}$} & \multirow[b]{2}{*}{ G } \\
\hline 4 & A & B & C & D & & & \\
\hline 1 & NIP & KodeJ & Kodept & Kodepst & Tglmasuk & TglLulus & Jalur \\
\hline 2 & S1 & 1019 & 21101 & $07 / 07 / 1980$ & $10 / 10 / 1986$ & 11 & 11 \\
\hline 3 & s2 & 71025 & 57401 & $07 / 07 / 2010$ & $10 / 10 / 2012$ & 11 & 11 \\
\hline 4 & & & & & & & \\
\hline 5 & & & & & & & \\
\hline 6 & & & & & & & \\
\hline
\end{tabular}

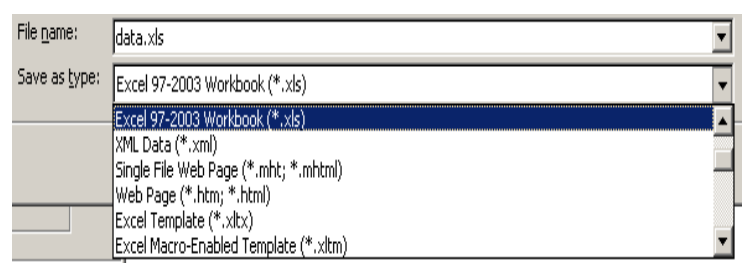

Gambar 14. Format Penyimpanan Exel

b. Import data

Pada database CV, dilakukan click kanan, kemudian click kiri pada all task, selanjutnya dipilih impor data, seperti diterangkan pada gambar 15.

Setelah itu ditentukan asal file dan tujuan import data pada gambar 16

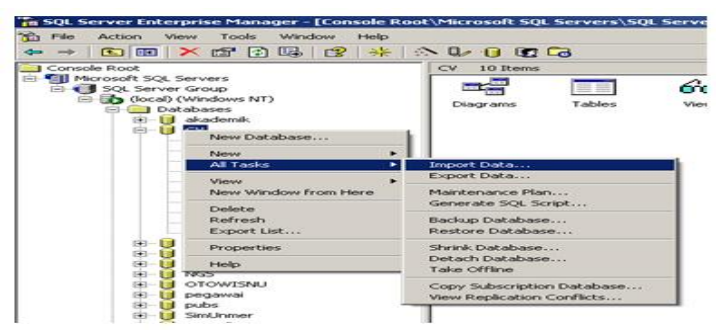

Gambar 15. Fasilitas Impor Data

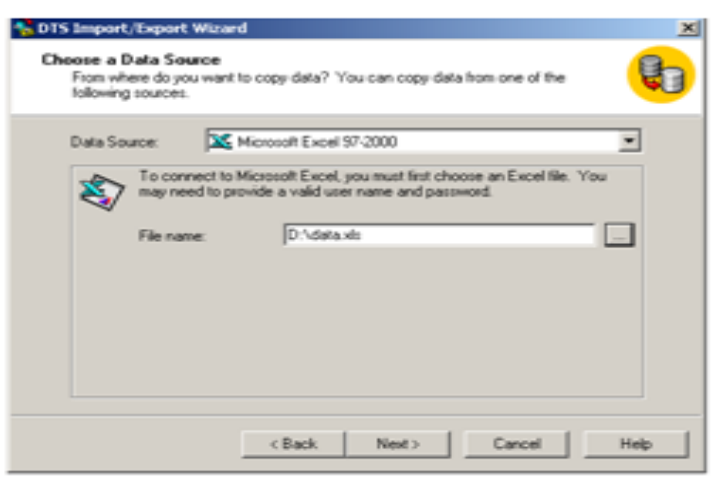

Gambar 16. Penentuan asal dan Tujuan file yang akan diimpor

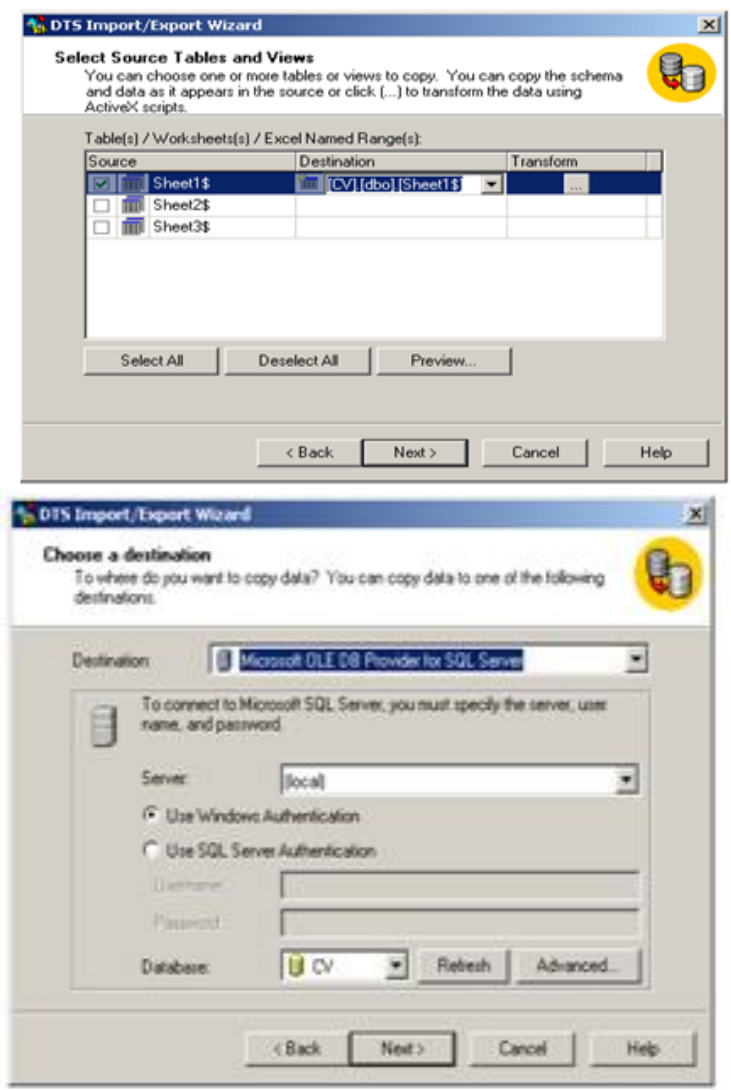

Gambar 17. Pilihan sheet yang akan diimpor ke SQL Server

Menu yang akan muncul adalah seperti tergambar pada gambar 17, dimana user akan memilih sheet yang akan diimpor. Dalam hal ini adalah sheet dimana data diisi. Selanjutnya diikuti perintah yang dituntun oleh aplikasi ini. 


\section{KESIMPULAN}

Berdasarkan rancangan yang telah dibuat yaitu desain aplikasi administrasi curiculum vitae dosen dilingkungan Universitas Merdeka Malang dapat simpulkan bahwa :

1. Desain aplikasi adminstrasi curiculum vitae dapat digunakan untuk pelayanan akademik dikampus, dan pelayanan dosen diluar kampus sehingga kebutuhan dosen dibidang akademik, kebutuhan lainya terkait curiculum vitae dapat dilayani dengan cepat.

2. Dalam penentuan kebijakan, desain aplikasi adminitrasi dapat dugunakan sebagai alat kontrol untuk mengetahui perkembangan setiap dosen dimasing-masing satker yang ada mengenai kegiatan tridarmana perguruan tinggi, juga bisa memberi motivasi bagi dosen yang lain untuk meningkatkan kegiatan tridarmanya serta kegiatan yang yang relevan diluar kampus.

\section{REFERENSI}

[1] Amsyah, Zulkifli,1997, Manajemen Sistem Informasi, PT Gramedia Pustaka Utama, Jakarta

[2] Eni Farida, 2011, Desain Sistem Informasi Mobile Akademik untuk Meningkatkan Kualitas Pelayanan di STMIK PPKIA Pradya Paramita Malang, Perpus PPS Unmer

[3] George H.Bodnar dan William S. Hopwood. 2003. Sistem Informasi Akuntansi. Edisi Kedelapan. Jilid 1. PT. Indeks, Kelompok Gramedia. Jakarta.

[4] http://curiculum vitae //jd.wi.org/

[5] Jauharul Maknunah,2010, Desain Sistem Penunjang Keputusan Jabatan Fungsional Akademik untuk Pengajuan Kepangkatan Dosen pada STMIK PPKIA Pradya Paramita Malang, Perpus PPS Unmer

[6] Jogiyanto, HM. 1999. Analisis Dan Desain Sistem Informasi: Pendekatan Terstruktur. Edisi Kedua. Cetakan Pertama. PT Andi. Yogyakarta.

[7] Jogiyanto, HM. 2005. Sistem Teknologi Informasi. Edisi Kedua. PT Andi. Yogyakarta.

[8] Mardiasmo. 2004. Akuntansi Sektor Publik. PT Andi. Yogyakarta

[9] Marshall B. Romney dan Paul John Steinbart. 2005. Accounting Information Systems. 9th Edition. Buku Satu. Salemba Empat. Jakarta.
[10] Marshall B. Romney dan Paul John Steinbart. 2005. Accounting Information Systems. 9th Edition. Buku Dua. Salemba Empat. Jakarta.

[11] Mulyanto .ague,2009, sistem Informasi Konsep \& Aplikasi. Cetakan Pertama pustaka Pelajar, Yoyakarta

[12] Raymond Mcleod, Jr. 2001. Sistem Informasi Manajemen. Edisi Ketujuh. Jilid 1. PT.Prenhallindo. Jakarta.

[13] Raymond Mcleod, Jr. 2001. Sistem Informasi Manajemen. Edisi Ketujuh. Jilid 2. PT.Prenhallindo. Jakarta.

[14] Solimun, 2000, Sistem Informasi manajemen ( Modul 1 ) Pascasarjana Univ. Islam Kediri

[15] Sanusi, Anwar, 2011, Metodologi Penelitian Bisnis, Salemba empat, Jakarta

[16] Undang-undang Republik Indonesia nomor 14 tahun 2005 